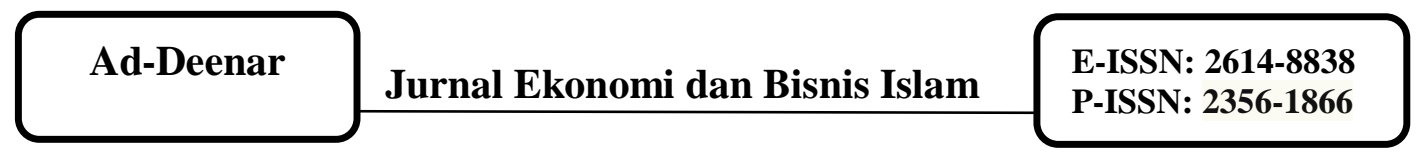

\title{
PRINSIP SALING RELA DALAM TRANSAKSI EKONOMI ISLAM (Tafsir Analitis Surat An-Nisa' [4] Ayat 29)
}

\author{
Ade Wahidin \\ Dosen Tetap Prodi Ilmu Al-Qur`an dan Tafsir STAI Al Hidayah Bogor \\ ade_wahidin17@mhs.uinjkt.ac.id
}

\begin{abstract}
One of the conditions of economic transactions in Islamic view is the mutual willingness between the two parties. So the discontent of either party or both parties make the transaction is invalid. This article would like to discuss about mutual willingness in economic transaction from various angle of view. Starting from the interpretation of the scholars about the letter al-Nisa verse 29 which contains the word 'an-tarädin (mutual willing), legal explanation, the rule of' antarạdin until its implementation in contemporary economic transactions that are factually dominated by mutual deeds that are deeds or local customs. In addition, the advancement of technology that has an impact on models of economic transactions that did not exist in the time of the Prophet, also became another dimension for the implementation of mutual willingness in economic transactions.
\end{abstract}

Keywords: mutual exchange, economic transactions.

\begin{abstract}
ABSTRAK
Salah satu syarat transaksi ekonomi dalam pandangan Islam adalah adanya saling rela antara kedua belah pihak. Sehingga ketidakrelaan dari salah satu pihak atau kedua belah pihak menjadikan batalnya transaksi alias tidak sah. Penelitian ini ingin mendiskusikan tentang saling rela dalam transaksi ekonomi dari berbagai sudut pandang. Mulai dari tafsir para ulama tentang Surat An-Nisa' [4] Ayat 29 yang memuat kata 'an-tarā ḍhin (saling rela), penjelasan hukumnya, kaidah 'antarạ̈hin hingga implementasinya dalam transaksi ekonomi kontemporer yang secara faktual didominasi oleh sikap saling rela yang bersifat perbuatan atau adat kebiasaan masyarakat setempat. Di samping itu, majunya teknologi yang berimbas pada model-model transaksi ekonomi yang tidak ada pada zaman Nabi, juga menjadi dimensi lain bagi implementasi sikap saling rela dalam transaksi ekonomi.
\end{abstract}

\section{A. PENDAHULUAN}

Dalam terminologi umum, manusia pada dasarnya adalah makhluk sosial, memiliki naluri untuk hidup dengan orang lain. Naluri manusia untuk selalu hidup dengan orang lain disebut gregariousness sehingga manusia juga disebut social animal (hewan sosial). Karena sejak dilahirkan manusia sudah mempunyai dua hasrat atau keinginan pokok, yaitu:

Pertama, Keinginan untuk menjadi satu dengan manusia lain di sekelilingnya (yaitu masyarakat). 
Kedua, Keinginan untuk menjadi satu dengan suasana alam sekelilingnya. ${ }^{1}$

Apabila dua orang bertemu, interaksi sosial dimulai pada saat itu. Mereka saling menegur, berjabat tangan, saling berbicara, atau bahkan mungkin berkelahi. Aktivitasaktivitas semacam itu merupakan bentukbentuk interaksi sosial. Walaupun orangorang yang bertemu muka tersebut tidak saling berbicara atau tidak saling menukar tanda-tanda, interaksi sosial telah terjadi, karena masing-masing sadar akan adanya pihak lain yang menyebabkan perubahanperubahan dalam perasaan maupun syaraf orang-orang yang bersangkutan, yang disebabkan oleh misalnya bau keringat, minyak wangi, suara berjalan, dan sebagainya. $^{2}$

Islam sebagai agama yang sempurna, datang dengan membawa ajaran yang universal dan komprehensif bagi seluruh aspek kehidupan manusia, baik aspek individual maupun sosial. Sehingga ajaran Islam tidak hanya mengatur seorang hamba supaya berindividual yang Islami tetapi juga bersosial yang Islami. Bahkan, bersosial Islami ini tidak hanya kepada sesama muslim tetapi juga kepada non muslim. ${ }^{3}$

${ }^{1}$ Soerjono Soekanto. (2012). Sosiologi Suatu Pengantar. Jakarta: PT RajaGrafindo Persada. 101.

${ }^{2}$ Soerjono Soekanto. (2012). hlm. 55.

3 Ade Wahidin. (2018). Tinjauan dan Hukum Tasyabbuh Perspektif Empat Imam Mazhab, $A L$
Tidak dipungkiri, bahwa dalam menjalani kehidupannya baik secara personal maupun sosial manusia pada dasarnya dituntut untuk memenuhi kebutuhannya. Tuntutan kebutuhan manusia itu bertingkat-tingkat, menurut AlSyathibi ada 3 (tiga) kategori tingkatan kebutuhan yaitu: ḍharūriyāt (kebutuhan primer), hăjiyāt (kebutuhan sekunder), dan tahsiniyāt (kebutuhan tersier):

1. Dharūriyāt, kebutuhan tingkat 'primer" adalah sesuatu yang harus ada untuk eksistensinya manusia atau dengan kata lain tidak sempurna kehidupan mansia tanpa harus dipenuhi manusia sebagai ciri atau kelengkapan kehidupan manusia, yaitu secara peringkatnya: agama, jiwa, akal, harta, dan keturunan. Kelima hal itu disebut al-dharuriyat alkhamsah (dharuriyat yang lima). Kelima dharuriyat tersebut adalah hal yang mutlak harus ada pada diri manusia. Karenanya Allah S.W.T. menyuruh manusia untuk melakukan segala upaya keberadaan dan kesempurnaannya. Sebaliknya Allah S.W.T. melarang melakukan perbuatan yang dapat menghilangkan atau mengurangi salah satu dari lima dharuriyat tersebut. Segala perbuatan yang dapat mewujudkan atau mengekalkan lima unsur pokok itu

MASHLAHAH: Jurnal Hukum Islam dan Pranata Sosial Islam. 06(01), hlm. 50. 


\section{Ad-Deenar

adalah baik, dan karenanya harus dikerjakan. Sedangkan segala perbuatan yang merusak atau mengurangi nilai lima unsur pokok itu adalah tidak baik, dan karenanya harus ditinggalkan. Semua itu mengandung kemaslahatan bagi manusia.

2. Hājiyāt, kebutuhan tingkat "sekunder" bagi kehidupan manusia yaitu sesuatu yang dibutuhkan bagi kehidupan manusia, tetapi tidak mencapai tingkat dharuri. Seandainya kebutuhan itu tidak terpenuhi dalam kehidupan manusia, tidak akan meniadakan atau merusak kehidupan itu sendiri. Namun demikian, keberadaannya dibutuhkan untuk memberikan kemudahan serta menghilangkan kesukaran dan kesulitan dalam kehidupan mukallaf.

3. Tahsiniyāt, kebutuhan tingkat "tersier" adalah sesuatu yang sebaiknya ada untuk memperindah kehidupan. Tanpa terpenuhinya kebutuhan tersebut kehidupan tidak akan rusak dan juga tidak akan menimbulkan kesulitan. Keberadaan kebutuhan tingkat ini sebagai penyempurna dari dua tingkatan kebutuhan sebelumnya, ia bersifat pelengkap dalam kehidupan mukallaf, yang dititikberatkan pada masalah etika dan estetika dalam kehidupan. ${ }^{4}$

Termasuk dalam hal ini, secara khusus yang menyangkut kebutuhan manusia dalam bidang ekonomi. Karena sudah menjadi sunnatullah bahwa antara satu manusia dengan yang lainnya saling memenuhi kebutuhannya dan tidak bisa berdiri sendiri.

Banyak barang yang dibutuhkannya dimiliki oleh orang lain, seperti seorang petani yang memiliki bahan pangan, dia juga membutuhkan pakaian maka dia harus menukar sebagian hasil panennya dengan uang dan membeli pakaian dengan uang tersebut, begitu juga sebaliknya. Dengan demikian dia mesti berinteraksi dengan orang lain untuk menutupi kebutuhannya. ${ }^{5}$

Aktifitas manusia bernilai ekonomi dalam Islam dikenal dengan istilah tasharruf, salah satu bentuknya adalah bertransaksi atau berakad yang merupakan landasan hukum bagi para pihak yang akan mengikatkan diri pada suatu kesepakatan usaha dengan diktum-diktum kesepakatan tertentu yang dibenarkan syara'. Sebagai suatu perjanjian bernilai ekonomi yang memiliki kekuatan hukum, suatu transaksi memiliki syarat dan rukunnya. Adapun

4 Muslimin Kara. (2012). Pemikiran AlSyathibi Tentang Maslahah. ASSETS. 2(02), hlm. 178-179.

5 Erwandi Tarmizi. (2017). Harta Haram Muamalat Kontemporer. Bogor: Berkat Mulia Insani. hlm. 49. 


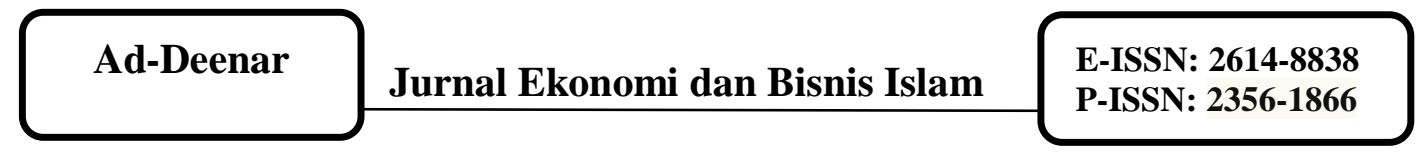

syarat sahnya adalah: Para pihak mukallaf, obyek akad diakui oleh syara', tidak dilarang syara', memenuhi syarat umum dan khusus, bermanfaat, adanya ijab dan qabul dan tujuannya jelas. Adapun rukunnya adalah: Pernyataan mengikatkan diri, pihak-pihak yang berakad dan obyek akad.

Adapun macamnya secara global terbagi dua, yaitu sah dan tidak sah yang varian masing-masing beragam dan selalu berkembang dari waktu ke waktu.

Adapun berakhirnya suatu akan terbagi menjadi dua: Dapat berakhir di tengah perjalanan dengan konsekuensi kerugian ditanggung oleh pihak yang mengundurkan diri dan berakhirnya akad setelah tujuan dan atau batas waktu yang ditentukan dengan ketentuan untung atau rugi ditanggung bersama. $^{6}$

Di samping itu, di antara syarat sahnya jual beli yaitu harus dilakukan oleh kedua pihak dengan saling rela (suka sama suka) tanpa ada unsur keterpaksaan. Seseorang yang terpaksa yaitu: orang yang berada di bawah ancaman fisik pihak lain yang mampu melakukan ancaman tersebut, bila

6 Syamsul Hilal. (2018). Transaksi dalam Hukum Islam, http://ejournal.radenintan.ac.id/index.php/asas/articl e/view/1702, diakses pada Rabu, 17 Januari 2018, Pukul 11: 30 WIB. pihak yang dipaksa tidak mau melakukan jual beli. ${ }^{7}$

Mengingat saling rela atau dalam bahasa Al-Qur`an Surat An-Nisa' [4] Ayat 29 dengan 'an-tarāọhin bagian dari syarat sah transaksi ekonomi dalam ajaran Islam, maka penulis tertarik mengeksplorasi masalah ini yang berbasis tafsir taḥlīli terhadap Surat An-Nisa' [4] Ayat 29. Kemudian penulis implementasikan pada transaksi-transaksi ekonomi kontemporer.

\section{B. TINJAUAN PUSTAKA}

Saling rela atau dalam bahasa AlQur`an Surat An-Nisa' Ayat 29 disebut dengan 'an-tarāọhin merupakan bagian dari syarat sah transaksi ekonomi dalam ajaran Islam. Secara teoritis, pernyataan ini teradvokasi dari interpretasi para ulama tafsir terhadap Surat An-Nisa' Ayat 29 yang tentunya diintegrasikan dengan tinjauan fikihnya.

Dalam penelitian ini, penulis merujuk ke beberapa ulama tafsir yang diakui kredibilitasnya baik yang klasik maupun kontemporer. Berikut ini uraian singkatnya terkait interpretasi Surat An-Nisa' Ayat 29, yang secara spesifik bermuara pada terma 'an-tarāạhin dalam bagan berikut:

\footnotetext{
${ }^{7}$ Erwandi Tarmizi. (2017). hlm. 49.
} 


\begin{tabular}{|c|c|c|}
\hline No & Nama Ahli Tafsir dan Kitabnya & Esensi Interpretasi \\
\hline 1 & $\begin{array}{c}\text { Al-Thabarī (w. } 310 \mathrm{H}) \\
\text { dalam kitabnya: } \\
\text { Jāmi’ Al-Bayān fì Ta 'wìl Ayyi Al- } \\
\text { Qur' } \bar{a} n\end{array}$ & $\begin{array}{l}\text { Al-Ṭhabarī dalam hal ini menukil beberapa } \\
\text { pandangan yaitu: Menurut Mujāhid makna } \\
\text { 'an-tarāọhin yaitu dalam hal berbisnis dan } \\
\text { seseorang memberikan hadiah kepada orang } \\
\text { lain. Menurut Maimūn ibn Mihrān makna 'an- } \\
\text { tarāḍhin yaitu sebagaimana sabda Rasulullah, } \\
\text { "Jual beli itu harus suka rela dari kedua belah } \\
\text { pihak, menentukan pilihan itu setelah tawar } \\
\text { menawar, dan tidak halal bagi seorang muslim } \\
\text { mencurangi muslim yang lain. }\end{array}$ \\
\hline 2 & $\begin{array}{c}\text { Ibn Katsīr (w. } 774 \text { H) } \\
\text { dalam kitabnya: } \\
\text { Tafsīr Al-Qur'ān Al-'Az̄ìm }\end{array}$ & $\begin{array}{l}\text { Menurut Ibn Katsīr pendapat mujtahid dari } \\
\text { kalangan Syafiiyah adalah pendapat yang kuat } \\
\text { tentang hakikat saling rela. Yaitu dengan } \\
\text { memperincinya (1) Jika komoditas tersebut } \\
\text { termasuk yang tidak begitu berharga, maka } \\
\text { saling rela bisa ditunjukkan dengan perbuatan } \\
\text { atau perilaku yang bergulir di adat kebiasaan } \\
\text { masyarakat setempat } \quad(2) \text { Jika komoditas } \\
\text { tersebut sangat berharga, maka tidak terwujud } \\
\text { saling rela kecuali dengan Ijab Kabul } \\
\text { perkataan. }\end{array}$ \\
\hline 3 & 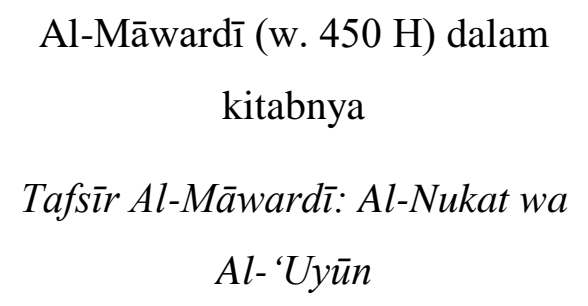 & $\begin{array}{l}\text { Saling rela menurut Al-Māwardī bisa } \\
\text { kesepakatan secara langsung bisa juga } \\
\text { memberikan pilihan setelah kesepakatan dan } \\
\text { sebelum berpisah. }\end{array}$ \\
\hline 4 & $\begin{array}{l}\text { Al-Syaukānī (w. } 1250 \text { H) dalam } \\
\text { kitabnya: Fath Al-Qadīr }\end{array}$ & $\begin{array}{l}\text { Perdagangan dalam bahasa maknanya saling } \\
\text { tukar menukar. Dalam ayat tersebut kata-kata } \\
\text { Al-Tijārah disebutkan sebagai istitsna }\end{array}$ \\
\hline
\end{tabular}




\begin{tabular}{|c|c|c|c|}
\hline & \multirow[t]{2}{*}{ Ad-Deenar } & \multicolumn{2}{|c|}{ Jurnal Ekonomi dan Bisnis Islam } \\
\hline & & & $\begin{array}{l}\text { munqati' yaitu pengecualian yang terputus. } \\
\text { Maksudnya adalah tetapi jika jual beli yang } \\
\text { dibangun di atas saling rela di antara kalian } \\
\text { maka hukumnya boleh. Atau maknanya tetapi } \\
\text { jika jual beli yang dibangun di atas saling rela } \\
\text { di antara kalian maka hukumnya halal. }\end{array}$ \\
\hline 5 & $\begin{array}{r}\text { Ibn 'Āshūr }( \\
\text { dalam ki } \\
\text { Tahrī̄ Al-Ma'n } \\
\text { Tanwīr Al-'Aql } \\
\text { Tafsīr Al-Kit }\end{array}$ & $\begin{array}{l}393 \text { H) } \\
\text { l-Sadìd wa } \\
\text { Jadìd Min } \\
\text { l-Majīd }\end{array}$ & $\begin{array}{l}\text { Menurut Ibn 'Āshūr, saling rela itu terwujud } \\
\text { bisa dengan memberikan pilihan setelah akad } \\
\text { bisa dengan perkataan dan bisa juga } \\
\text { dikembalikan kepada adat kebiasaan } \\
\text { masyarakat setempat. Dan secara implisit ia } \\
\text { sependapat dengan Imam Malik yang tidak } \\
\text { mensyaratkan khiyār (pemberian pilihan dalam } \\
\text { jual beli). }\end{array}$ \\
\hline 6 & $\begin{array}{r}\text { Al-Zuhailī ( } \\
\text { dalam K } \\
\text { Al-Tafsìr Al-Mur } \\
\text { wa Al-Syarī'ah } \\
\text { da } \\
\text { Al-Tafsìr }\end{array}$ & $\begin{array}{l}436 \mathrm{H}) \\
\text { nya: } \\
\text { Al-'Aqīdah } \\
\text { Al-Manhaj } \\
\text { Wasịt }\end{array}$ & $\begin{array}{l}\text { Menurut Al-Zuhailī saling rela itu bentuknya } \\
\text { ada tiga yaitu (1) Adanya ucapan Ijab Kabul } \\
\text { (2) Adanya pemberian hak pilih (3) Perilaku } \\
\text { atau perbuatan yang menunjukkan saling rela. }\end{array}$ \\
\hline
\end{tabular}

\section{Redaksi 'An-Tarādin dalam Al- Qur`an}

Berdasarkan eksplorasi penulis terhadapa ayat-ayat Al-Qur`an melalui aplikasi Maktabah Syāmilah, maka ayat yang memuat di dalamnya kata atau lebih tepatnya disebut dengan frasa 'an-tarạ berjumlah dua ayat, yaitu Surat Al-Baqarah Ayat 233 dan Surat An-Nisa Ayat 29:

\section{Surat Al-Baqarah Ayat 233 dan Artinya}

Dalam Surat Al-Baqarah Ayat 233 ini, secara kontekstual berbicara tentang 
masalah penyusuan ibu terhadapa anaknya dan hal-hal teknis lainnya terkait dengan penyusuan. Allah Ta'la berfirman:

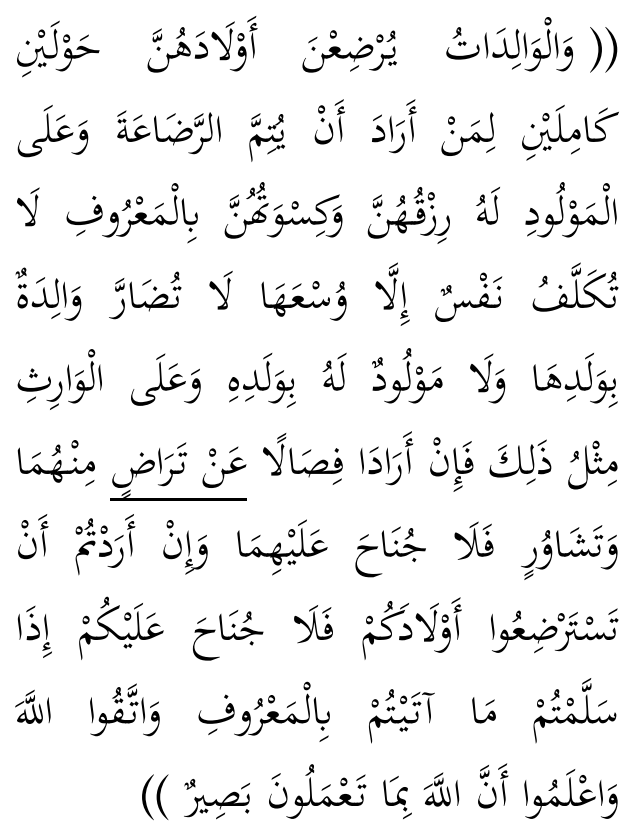

Para ibu hendaklah menyusukan anak-anaknya selama dua tahun penuh, yaitu bagi yang ingin menyempurnakan penyusuan. Dan kewajiban ayah memberi makan dan pakaian kepada para ibu dengan cara ma'ruf. Seseorang tidak dibebani melainkan menurut kadar kesanggupannya. Janganlah seorang ibu menderita kesengsaraan karena anaknya dan seorang ayah karena anaknya, dan warispun berkewajiban demikian. Apabila keduanya ingin menyapih (sebelum dua tahun) dengan kerelaan keduanya dan permusyawaratan, maka tidak ada dosa atas keduanya. Dan jika kalian ingin anak kalian disusukan oleh orang lain, maka tidak ada dosa bagi kalian apabila kalian memberikan pembayaran menurut yang patut. Bertakwalah kalian kepada Allah dan ketahuilah bahwa Allah Maha Melihat apa yang kalian kerjakan. (Q.S. Al-Baqarah [2]: 233)

\section{Surat An-Nisa' [4] Ayat 29 dan Artinya}

Dalam Surat An-Nisa' Ayat 29 ini, dijelaskan tentang larangan memakan harta manusia secara batil kecuali perdagangan yang didasarkan atas suka sama suka. Allah Ta'ala berfirman:

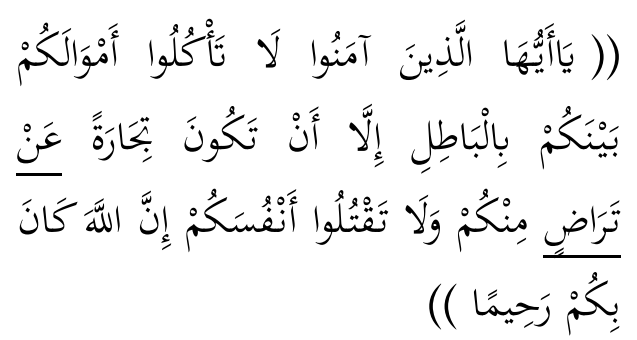

Hai orang-orang yang beriman, janganlah kalian saling memakan harta sesama kalian dengan jalan yang batil, kecuali dengan jalan perniagaan yang berlaku dengan suka sama-suka di antara kalian. Dan janganlah kalian membunuh diri kalian; sesungguhnya Allah adalah Maha Penyayang kepadamu. (Q.S. An-Nisa' [4]: 29)

\section{PANDANGAN AHLI TAFSIR TENTANG SURAT AN-NISA' AYAT 29}

Pada bagian ini, penulis akan menguraikan pandangan para Ahli Tafsir terkait tentang makna Surat An-Nisa' Ayat 29 secara umum dan makna 'An-Taräạhhīn secara khusus. Baik ahli tafsir klasik maupun kontemporer, berikut ini penjelasannya:

\section{Al-Ṭabarī (w. 310 H)}

Berkaitan dengan Surat An-Nisa' Ayat 29, Al-Ṭhabarī menafsirkan dengan katakata, "Janganlah sebagian kalian memakan harta sebagian yang lainnya dengan cara 


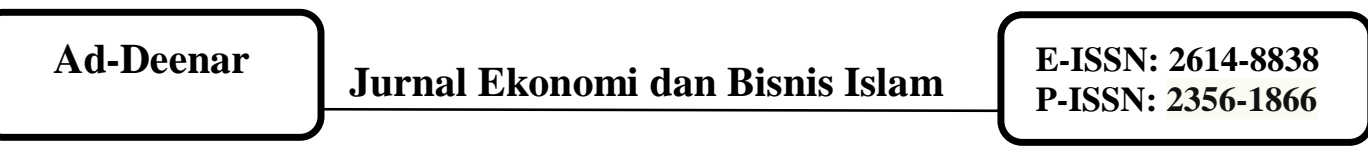

yang diharamkan seperti riba, judi, dan lain sebagainya kecuali berupa jual beli." ${ }^{8}$

Al-Ṭabarī juga menjelaskan bahwa ayat ini terdapat penjelasan dari Allah tentang bantahan terhadap para Sufi yang dangkal ilmunya yang mengingkari pencarian rezeki dengan cara berbisnis dan berindustri. Karena Allah berfirman, "Hai orang-orang yang beriman, janganlah kalian saling memakan harta sesama kalian dengan jalan yang batil, kecuali dengan jalan perniagaan yang berlaku dengan suka sama-suka di antara kalian." Maksudnya kita harus bekerja dan berusaha salah satunya dengan berbisnis. $^{9}$

Adapun terkait makna 'an-tarāọhin, Al-Ṭabarī dalam hal ini menukil beberapa pandangan yaitu: Menurut Mujāhid makna 'an-tarạdhin yaitu dalam hal berbisnis dan seseorang memberikan hadiah kepada orang lain. Menurut Maimūn ibn Mihrān makna 'an-tarāọhin yaitu sebagaimana sabda Rasulullah, "Jual beli itu harus suka rela dari kedua belah pihak, menentukan pilihan itu setelah tawar menawar, dan tidak halal

${ }^{8}$ Muhammad ibn Jarīr ibn Yazīd ibn Katsīr ibn Ghālib Al-Āmilī Abū Ja'far Al-Ṭhabarī. (2000). Jāmi’ Al-Bayān fì Ta 'wōl Al-Qur 'àn, Tahqīq: Ahmad Muhammmad Syākir, Muassasah Al-Risalah, Juz: 8, hlm. 216.

${ }^{9}$ Muhammad ibn Jarīr ibn Yazīd ibn Katsīr ibn Ghālib Al-Āmilī Abū Ja'far Al-Tabarī. (2000). hlm. 220. bagi seorang muslim mencurangi muslim yang lain." 10

Selanjutnya Al-Ṭhabarī menjelaskan tentang perbedaan pendapat di kalangan para ulama tentang makna an-tarāạh $\bar{\imath}$ dalam konteks jual beli.

Pendapat pertama, Sebagian ulama menyatakan bahwa makna an-tarāọh adalah memberikan pilihan kepada masingmasing pihak baik pembeli maupun penjual setelah disepakati akadnya apakah dilanjutkan transaksinya ataukah dibatalkan. Atau maksud an-tarāọh $\bar{\imath}$ itu setelah pembeli dan penjual tersebut berpisah secara fisik yang otomatis menunujukkan saling rela terhadap akad jual belinya sebelum adanya pembatalan dari masing-masing pihak.

Mereka beralasan bahwa model jual beli yang berdasarkan saling ridho adalah sebagaimana yang dijelaskan oleh Nabi Muhammad Shallallahu 'alihi Wasallam yaitu:

a. Memberikan pilihan kepada pembeli dan penjual untuk meneruskan atau membatalkan atas akad jual beli yang disepakati sebelumnya, atau

b. Dengan berpisahnya antara pembeli dan penjual secara fisik setelah akad

${ }^{10}$ Muhammad ibn Jarīr ibn Yazīd ibn Katsīr ibn Ghālib Al-Āmilī Abū Ja'far Al-Ṭhabarī. (2000). hlm. 221. 


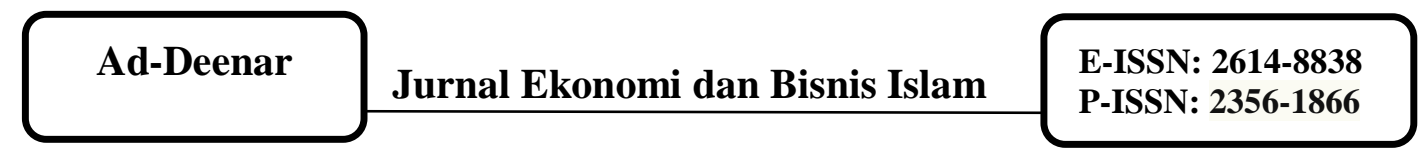

jual beli tersebut disepakati oleh keduanya.

Oleh karena itu, selain kedua model di atas maka tidak disebut dengan jual beli yang berdasarkan saling ridha.

Pendapat kedua, saling ridha itu dapat direalisasikan secara otomatis setelah disepakatinya akad jual beli antara pembeli dan penjual yang ditandai dengan berpindahnya kepemilikan barang dan alat tukar dari pemilik sebelumnya tanpa memandang apakah keduanya sudah berpisah atau belum dan tanpa melihat apakah keduanya telah diberikan pilihan untuk lanjut akadnya atau tidak.

Alasannya adalah karena hakikat jual beli itu dengan perkataan sebagaimana dalam pernikahan. Para ulama sepakat tentang sahnya akad pernikahan walaupun dipaksa salah satu mempelainya, baik itu keduanya berpisah dari majlis akad pernikahan tersebut atau tidak. Maka, demikian pula dengan jual beli.

Adapun terkait hadis Nabi Muhammad, "Akad jual beli itu ditetapkan dengan memberikan pilihan selama belum berpisah dari tempat akadnya." Maka ditakwilkan maknanya yaitu selama belum berpisah dari tempat akadnya dengan adanya perkataan yang membatalkan akad tersebut. Pandangan ini sebagaimana dikutip dari
Imam Malik, Imam Abu Hanifah, Imam Abu Yusuf, dan Imam Muhammad.

Setelah menguraikan dua pandangan tersebut, Al-Ṭhabarī memberikan kesimpulan pendapat yang paling kuat dengan kata-kata sebagai berikut:

$$
\begin{aligned}
& \text { (( وأولى القولين بالصواب في ذلك عندنا، } \\
& \text { قولُ من قال: إن التجارة التي هي عن لن } \\
& \text { تراض بين المتبايعين، ما تفرّق المتبايعان عن } \\
& \text { المجلس الذي تواجبًا فيه بينهما عُقدة البيع } \\
& \text { بأبداهما، عن تراض منهما بالعقد الذي } \\
& \text { جرى بينهما، وعن تخيير كل واحد منهما } \\
& \text { صاحبه لصحة الخبر عن رسول الله صلى } \\
& \text { الله عليه وسلم6بما: حدثني يعقوب بن } \\
& \text { إبراهيم قال، حدثنا ابن علية قال، أخبرنا } \\
& \text { أيوب وحدثنا ابن بشار قال، حدثنا عبد } \\
& \text { الوهاب قال، حدثنا أيوب عن نافع، عن ائن } \\
& \text { ابن عمر قال، قال رسول الله صلى الله عليه }
\end{aligned}
$$

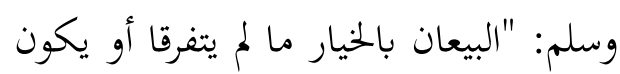

$$
\begin{aligned}
& \text { بيعَ خيار" وربما قال: "أو يقول أحدهما } \\
& \text { لآخر اختر "() }
\end{aligned}
$$

"Menurut kami, pendapat yang paling kuat di antara dua pendapat tersebut adalah pendapat yang pertama yaitu bahwa jual beli yang berdasarkan saling ridha itu adalah ketika kedua pihak baik pembeli dan penjual telah berpisah fisik dari tempat akad tersebut setelah transaksinya selesai disepakati. Demikian pula saling ridha itu tercermin dengan diberikannya pilihan kepada kedua pihak apakah dilanjutkan atau 


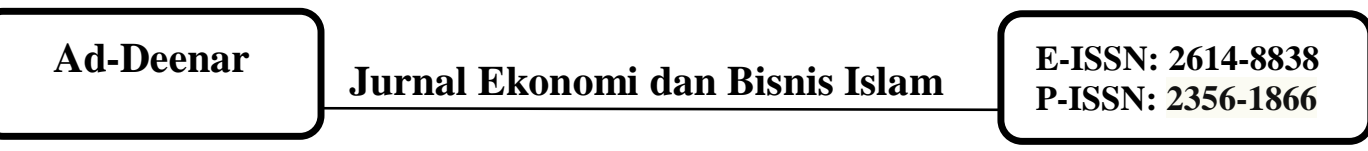

tidak. Hal ini berdasarkan hadis yang valid dari Nabi Muhammad.

Telah mengkhabarkan kepadaku Ya'qub ibn Ibrahim, ia berkata: telah mengkhabarkan kepada kami Ibn 'Aliyyah, ia berkata: telah mengkhabarkan kepada kami Ayyub, telah mengkhabarkan kepada kami Ibn Basyyar, ia berkata, telah mengkhabarkan kepada kami Abdul Wahhab ia berkata, telah mengkhabarkan kepada kami Ayyub dari Nafi' dari Ibn 'Umar ia berkata, Rasulullah bersabda, "Akad jual beli itu disahkan dengan adanya pemberian pilihan kepada kedua pihak selama belum berpisah atau pilihan tersebut betul-betul diberikan dalam akad jual beli tersebut." Terkadang Nabi bersabda, "Atau salah satu pihak berkata kepada pihak lainnya, 'Pilihlah'."'11

Dari urain tersebut, dapat disimpulkan bahwa menurut Al-Ṭabarī saling ridha memiliki dua varian (1) adanya pemberian pilihan kepada kedua pihak yaitu pembeli dan penjual apakah dilanjutkan atau tidak transaksinya (2) Atau dengan berpisahnya fisik kedua pihak dari tempat jual beli tersebut.

\section{Ibn Katsīr (w. 774 H)}

Berkaitan dengan Surat An-Nisa' Ayat 29 ini, Ibn Katsīr menjelaskan bahwa Allah Ta'ala telah melarang hamba-hamba-Nya yang beriman dari memakan harta orang lain dengan cara yang batil. Yaitu segala

11 Muhammad ibn Jarīr ibn Yazīd ibn Katsīr ibn Ghālib Al-Āmilī Abū Ja'far Al-Ṭhabarī. (2000). hlm. 222-228. bentuk usaha mendatangkan harta yang tidak disyariatkan seperti riba dengan segala variannya, perjudian, dan seluruh bentuk transaksi yang mengandung penipuan dan spekulasi. Walaupun secara lahir hukum syar'inya hanya Allah yang mengetahui bahwa transaksi tersebut dilakukan oleh para pelakunya dalam rangka ingin mengelak dari perbuatan riba. $^{12}$

Adapun terkait makna saling ridha, maka Ibn Katsīr menukil pendapat Imam Syafii bahwa ayat ini dijadikan dalil oleh Syafii Semoga Allah merahmatinya bahwa jual beli itu tidak sah kecuali dengan adanya ijab dan kabul. Karena hal ini menunjukkan keridhaan secara verbal. Berbeda dengan Al-Mu'āțāh (jual beli tanpa adanya perkataan ijab kabul), maka ini tidak menunjukkan saling ridha secara pasti.

Pendapat Syafii ini menyelisihi mayoritas ulama seperti Abu Hanifah, Malik, dan Ahmad ibn Hanbal serta para pengikutnya. Mereka berpandangan bahwa sebagaimana kata-kata itu menunjukkan keridhaan maka demikian pula dengan perbuatan yang terkadang menunjukkan sesuatu yang pasti. Sehingga secara mutlak

12 Abū Al-Fidā Ismā'īl ibn 'Umar ibn Katsīr Al-Qurashī Al-Bașrī Tsumma Al-Dimashqī. (1999). Tafsīr Al-Qur'ān Al- 'Až̄im. Juz: 2, Taḥqīq: Sāmī ibn Muhammad Salāmah, Dār Al-Ṭaibah, hlm. 268. 
mereka membolehkan jual beli tanpa Ijab Kabul perkataan.

Ada juga para ulama yang mengatakan bahwa jual beli tanpa ijab Kabul perkataan ini sah pada komoditas yang rendahan dan sepele serta yang dianggap secara adat kebiasaan bahwa itu adalah transaksi jual beli. Dan ini adalah pendapat yang lebih hati-hati dari para Mujtahid mazhab, Wallahu A'lam. ${ }^{13}$

Jadi, menurut Ibn Katsīr pendapat mujtahid dari kalangan Syafiiyah adalah pendapat yang kuat tentang hakikat saling rela. Yaitu dengan memperincinya (1) Jika komoditas tersebut termasuk yang tidak begitu berharga, maka saling rela bisa ditunjukkan dengan perbuatan atau perilaku yang bergulir di adat kebiasaan masyarakat setempat (2) Jika komoditas tersebut sangat berharga, maka tidak terwujud saling rela kecuali dengan Ijab Kabul perkataan.

\section{Al-Māwardī (w. 450 H)}

Al-Māwardī dalam kitab tafsirnya menjelaskan tentang makna Surat Al-Nisa Ayat 29 bahwa dalam hal ini terdapat tiga pendapat tentang arti memakan harta manusia secara batil. Pertama, dengan cara zina, judi, curang, dan kezaliman. Ini merupakan pendapat Al-Suddī. Kedua, maksudnya adalah transaksi-transaksi yang

${ }^{13}$ Abū al-Fidā Ismā'īl ibn 'Umar ibn Katsīr AlQurashī Al-Bașrī Tsumma Al-Dimashqī. (1999). hlm. 269. rusak, ini merupakan pendapat Ibn 'Abbas.

Ketiga, Allah melarang seseorang memakan makanan yang dihidangkan untuk tamu dan diperintahkan untuk memakannya berdasarkan akad jual beli. Kemudian, syariat ini dihapus dengan firman Allah Surat An-Nur Ayat 61, "Tidak mengapa diri kalian memakan makanan dari rumahrumah kalian," hingga firman-Nya, "atau memakannya secara berpisah-pisah. Pendapat ini dikatakan oleh Al-Hasan dan 'Ikrimah. ${ }^{14}$

Adapun terkait makna saling rela, maka Al-Māwardī menjelaskannya dengan katakata berikut:

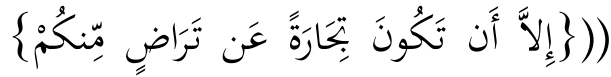

$$
\begin{aligned}
& \text { فيه قولان: أحدهما: أن التراضي هو أن } \\
& \text { يكون العقد ناجزاً بغير خيار , وهو قول } \\
& \text { مالك , وأبي حنيفة. والثاني: هو أن يخير } \\
& \text { أحدهما صاحبه بَعد العقد وقبل الافتراق , } \\
& \text { وهو قول شريح , وابن سيرين , والشعبي. } \\
& \text { وقد روى القاسم بن سليمان الحنفي عن } \\
& \text { أبيه عن ميمون بن مهران قال: قال رسول } \\
& \text { الله صلى الله عليه وسلم: (البَيْعُ عَنْ تَرَاضٍ }
\end{aligned}
$$

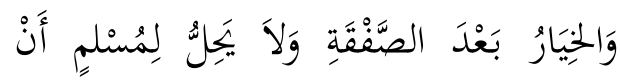

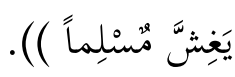

14 Abū Al-Ḥasan 'Alī ibn Muhammad ibn Muhammad ibn Ḥabīb Al-Bașrī Al-Baghdādī yang terkenal dengan sebutan Al-Māwardī, Tafsīr AlMāward̄̄: Al-Nukat wa Al- 'Uyūn. Tahqū̄q: Al-Sayyid ibn 'Abd Al-Maqșūd ibn 'Abd Al-Raḥīm, Dar alKutub Al-'Ilmiyah: Beirut Libanon, Jilid1, hlm. 474. 


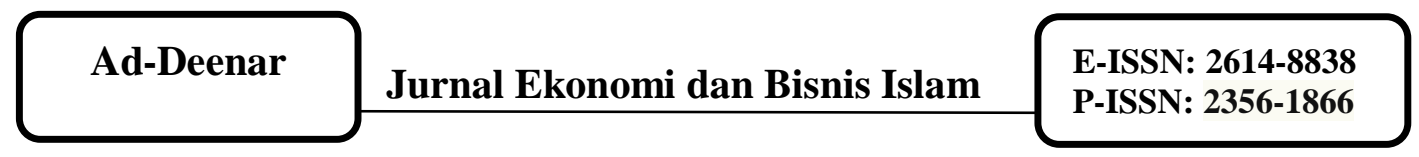

"Firman Allah, "Kecuali perdagangan yang dibangun atas dasar saling rela." Mengandung dua pandangan. Pertama, saling rela itu maksudnya adalah suatu akad yang telah disepakati secara langsung tanpa diberikan pilihan setelahnya. Pandangan ini dipegang oleh Imam Malik dan Imam Abu Hanifah. Kedua, maksud saling rela itu adalah setelah akad jual beli tersebut disepakati dan sebelum berpisah, baik pembeli maupun penjual diberikan pilihan untuk melanjutkan akadnya atau tidak. Pandangan ini dipegang oleh Syuraih, Ibn Sirin, dan al-Sya'bi. Hal ini sebagaimana hadis yang diriwayatkan oleh al-Qasim ibn Sulaiman al-Hanafi dari bapaknya dari Maimun ibn Mihran berkata. Rasulullah bersabda, "Jual beli itu harus berdasarkan saling rela. Memberikan pilihan itu setelah tawar menawar. Tidak halal bagi seorang muslim berbuat curang kepada muslim lainnya."15

Jadi, saling rela menurut Al-Māwardī bisa kesepakatan secara langsung bisa juga memberikan pilihan setelah kesepakatan dan sebelum berpisah. Walaupun menurut penulis, Al-Māward̄̄ secara implisit menguatkan pandangan yang kedua yang menyatakan adanya pemberian pilihan. Karena Al-Māwardī mencantumkan hadis sebagai penguat argumentasi pandangan yang kedua. Di samping itu, pandangan ini juga sejalan dengan mazhab fikih yang dianut oleh Al-Māwardī yaitu mazhab Syafii.

15 Abū Al-Hasan 'Alī ibn Muhammad ibn Muḥammad ibn Hạīio Al-Bașrī Al-Baghdādī yang terkenal dengan sebutan Al-Māwardī. hlm.475.

\section{Al-Syaukānī (w. 1250 H)}

Muhammad ibn 'Alī ibn Muḥammad ibn 'Abdullāh Al-Syaukān̄̄ Al-Yaman̄̄ menjelaskan makna Surat An-Nisa’ Ayat 29 bahwa $A l-B \bar{a} t h i l$ adalah segala sesuatu yang bukan kebenaran. Batil ini banyak dimensinya. Di antara perkara batil adalah segala bentuk transaksi ekonomi yang dilarang oleh syariat.

Perdagangan dalam bahasa maknanya saling tukar menukar. Dalam ayat tersebut kata-kata Al-Tijārah disebutkan sebagai istitsnā munqați' yaitu pengecualian yang terputus. Maksudnya adalah tetapi jika jual beli yang dibangun di atas saling rela di antara kalian maka hukumnya boleh. Atau maknanya tetapi jika jual beli yang dibangun di atas saling rela di antara kalian maka hukumnya halal. ${ }^{16}$

Lalu Al-Syaukān̄̄ menyebutkan tentang pandangan para ulama tentang makna saling rela dalam perdagangan yang bermuara pada dua pendapat yaitu:

a. Makna saling rela yang sempurna dan wajib adalah dengan berpisahnya pembeli dan penjual dari tempat jual belinya setelah akadnya disepakati atau dengan salah satu di antara keduanya mengatakan kepada yang lain "Silahkan pilih." Hal ini

16 Muhammad ibn 'Alī ibn Muhammad ibn 'Abdullāh Al-Syaukānī Al-Yaman̄. (1414 H). Beirut: Dar Ibn Katsir, Jilid 1, hlm. 526. 


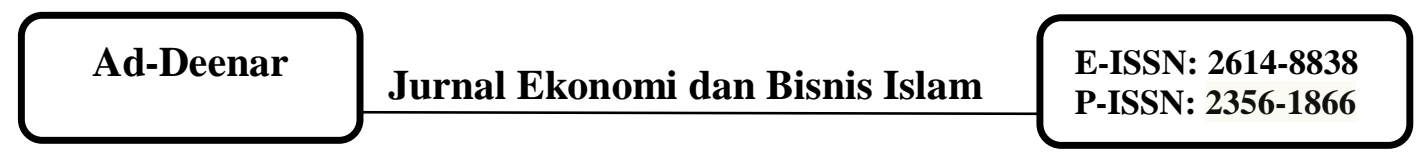

sebagaimana yang disebutkan dalam hadis sahih berikut:

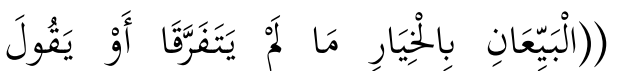

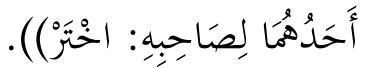

"Transaksi jual beli itu terwujud dengan memberikan pilihan selama belum berpisah antara pembeli dan penjual atau salah satunya berkata kepada yang lainnya, 'Silahkan pilih."

Pandangan ini dipegang oleh segolongan sahabat, tabiin, Syafii, AlTsauri, Al-Auza'I, Al-Laits, Ibn 'Uyainah, Ishaq, dan lainnya.

b. Transaksi jual beli itu sempurna yaitu dengan diucapkan ijab Kabul secara lisan, sehingga tidak perlu lagi memberikan pilihan. Pandangan ini dikatakan oleh Malik dan Abu Hanifah. Mereka menjawab hadis yang menyatakan adanya pemberian pilihan dengan jawaban yang tidak memuaskan. ${ }^{17}$

\section{Ibn 'Āshūr (w. 1393 H)}

Ketika menafsirkan Surat Al-Nisa' Ayat 29, Ibn 'Āshūr menyatakannya dengan kata-kata berikut:

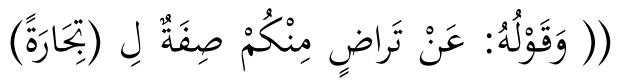

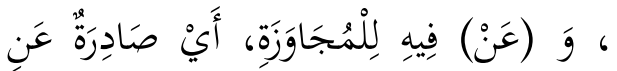

17 Muhammad ibn 'Alī ibn Muhammad ibn 'Abdullāh Al-Syaukān̄i Al-Yaman̄̄. (1414 H). Fath Al-Qadīr. Beirut: Dar Ibn Katsir, Jilid 1, hlm. 526.

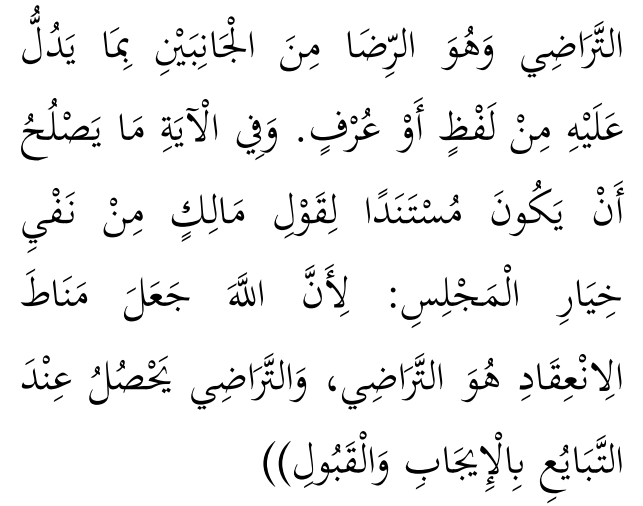

Firman Allah "'An Tarāḍin Minkum" merupakan sifat untuk kata Tijārah. Kata 'An bermakna melalui. Maksudnya perdagangan tersebut melalui kerelaan dari kedua pihak baik itu secara verbal maupun berdasarkan 'urf (adat kebiasaan setempat). Dalam ayat ini, dapat dijadikan sebagai landasan argumentasi pandangan Imam Malik yang menegasikan khiyār (pemberian pilihan dalam jual beli). Karena Allah telah menjadikan patokan terwujudnya akad jual beli itu adalah adanya saling rela. Berdasarkan eksplorasi, saling rela itu terwujud melalui Ijab dan Kabul (tanpa harus memberikan pilihan setelah itu). ${ }^{18}$

Jadi, menurut Ibn 'Āshūr, saling rela itu terwujud bisa dengan memberikan pilihan setelah akad bisa dengan perkataan dan bisa juga dikembalikan kepada adat kebiasaan masyarakat setempat. Dan secara implisit ia sependapat dengan Imam Malik yang tidak mensyaratkan khiyār (pemberian pilihan dalam jual beli).

18 Muhammad Al-Ṭāhir ibn Muḥammad ibn Muhạmmad Al-Ṭāhir ibn 'Āshūr Al-Tūnisi. (1984). Tah̆rīr al-Ma'na Al-Sadīd wa Tanwīr Al-'Aql AlJadīd Min Tafsīr Al-Kitāb Al-Majīd. Tunis: al-Dar al-Tunisiah, Jilid 5, hlm. 24. 


\section{Ad-Deenar

\section{Al-Zuḥailī (w. $1436 \mathrm{H}$ ) ${ }^{19}$}

Salah seorang ulama kontemporer yang bernama Wahbah ibn Muṣtafā Al-Zuhailī dalam kitab tafsirnya yang berjudul AlTafsīr Al-Wașịt mengatakan ketika mengomentari firman Allah dalam alQur`an Surat Al-Nisa' Ayat 29 bahwa ayat ini mengharamkan perbuatan zalim atau melampaui batas terhadap harta dan jiwa.

Di mana tidak dihalalkan seseorang memakan harta orang lain dengan cara yang batil. Yaitu cara yang tidak disyariatkan dan diambil dari jenis-jenis harta atau manfaatmanfaat suatu komoditas secara zalim tanpa adanya imbalan.

Hal ini mencakup juga setiap harta yang diambil melalui transaksi yang batil atau rusak. Seperti seseorang yang menjual sesuatu yang tidak ia miliki. Harta hasil penjualan komoditas makanan yang tidak bisa diambil manfaatnya lagi seperti kelapa, telur, dan lobak yang sudah tidak layak makan. Demikian pula harta hasil penjualan komoditas yang secara syariat tidak memiliki harga dan manfaat seperti jual beli monyet, babi, lalat, tawon, bangkai, arak, upah untuk tim yang menangisi mayit, dan

19 Wahbah Al-Zuhailī lajir di Dair 'Athiyah Damaskus Suriah pada Tahun 1351 H. (1932) dan meninggal dunia pada hari Minggu 24 Syawwal 1436 H. di Damaskus dalam usia 83 tahun. Lihat Rahendra Maya. (2018). “Atensi Al-Qur'an Terhadap Anak Yatim (Studi Al-Tafsîr Al-Wasîth Karya Wahbah Al-Zuhailî). Al-Tadabbur: Jurnal Ilmu Al-Qur'an dan tafsir. 03(02). hlm. 163. alat musik. Maka barangsiapa yang melakukan jual beli yang rusak semacam yang telah disebutkan dan ia mengambil hasil penjualannya atau mengambil upahnya, maka hasilnya tersebut haram dan tercela, wajib dikembalikan kepada pemiliknya. Akan tetapi dibolehkan untuk mengambil harta orang lain berdasarkan saling rela dalam transaksi-transaksi yang sah dan tentunya diizinkan syariat seperti meminjam, hibah, jual beli, sewa-menyewa. Hal ini berdasarkan firman Allah, "Kecuali jual beli yang berdasarkan saling rela di antara kalian." Maksudnya "makanlah harta melalui cara perdagangan yang dibangun di atas saling rela baik berupa jual beli atau sewa-menyewa."20

Tidaklah setiap saling rela itu otomatis boleh secara syariat akadnya. Akan tetapi saling rela ini harus dilihat boleh tidaknya akad tersebut berdasarkan dzat akad tersebut. Maka harta ribawi tidak boleh ditransaksikan baik dalam jual beli maupun simpan pinjam yang menarik manfaat. Demikian pula harta yang dihasilkan dari perjudian dan pegadaian walaupun kedua pihak saling rela. Karena hal ini bertentangan dengan syariat Allah.

Adapun terkait makna saling rela dalam transaksi ekonomi, maka Al-Zuhailī

${ }^{20}$ Wahbah ibn Mușṭafā Al-Zuhailī. (1422 H). Al-Tafsīr Al-Wasìt. Damaskus: Dar Al-Fikr, Jilid 1, hlm. 310 . 
menyebutkannya secara eksplisit dengan kata-kata sebagai berikut:

$$
\begin{aligned}
& \text { (( وتمام التراضي: أن يعقد البيع بالألسنة } \\
& \text { بالإيجاب والقبول، فتنتقل ملكية المبيع } \\
& \text { للمشتري، ويجب على المشتري الوفاء }
\end{aligned}
$$

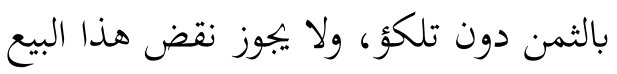

$$
\begin{aligned}
& \text { من أحد الطرفين دون موافقة الآخر، ولا هالا }
\end{aligned}
$$

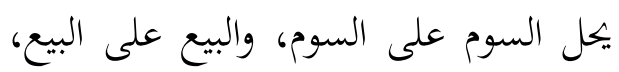

$$
\begin{aligned}
& \text { والخطبة على الخطبة،لقول النبي صلّى الله } \\
& \text { عليه وسلّم في الحديث المتفق عليه: الالا } \\
& \text { يسم الرجل على سوم أخيه، ولا يبيع الرجل }
\end{aligned}
$$

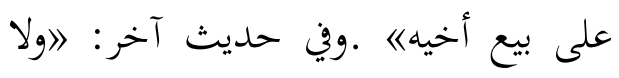

$$
\begin{aligned}
& \text { يخطب الرجل على خطبة أخيه)). }
\end{aligned}
$$

Saling rela dalam transaksi itu secara idealnya adalah disepakatinya akad jual beli secara lisan yang ditunjukkan dengan Ijab dan Kabul. Sehingga berpindahlah kepemilikan barang dari penjual ke pembeli. Wajib bagi pembeli memberikan harga barang tersebut tanpa menangguhkannya. Tidak boleh akad ini dibatalkan tanpa adanya kesepakatan dari kedua belah pihak. Tidak boleh seseorang menawar di atas tawaran orang lain. Demikian pula dalam jual beli dan meminang. Karena Nabi bersabda sebagaimana dalam hadis yang disepakati oleh Bukhari dan Muslim, "Tidak boleh seseorang menawar barang yang sedang ditawar oleh saudaranya, tidak boleh juga seseorang membeli barang yang sedang dibeli oleh saudaranya." Dalam riwayat yang lain, "Tidak boleh seseorang meminang perempuan yang sedang berada dalam pinangan
saudaranya." 21

Dalam kitab tafsirnya yang lain yang berjudul Al-Tafsīr al-Munīr fì Al-'Aqīdah wa Al-Syarī'ah wa Al-Manhaj, Al-Zuhailī menyebutkan makna lain tentang Al-Tarāậ (suka sama suka/saling rela) dengan katakata berikut:

$$
\begin{aligned}
& \text { (( ومن تمام التراضي إثبات خيار المجلس، } \\
& \text { الذي قال به الشافعي وأحمد والليث } \\
& \text { وغيرهم، لما } \\
& \text { ثبت في الصحيحين: أن رسول الله صلّى } \\
& \text { الله عليه وسلّم قال: البيّعان بالخيار ما لم } \\
& \text { يتفرقا《وفي لفظ البخاري: إإذا تبايع } \\
& \text { الرجلان، فكل واحد منهما بالخيار ما لم } \\
& \text { يتفرقا } \\
& \text { يعني أن الآية خخصوصة بالحديث. ومن } \\
& \text { ذلك مشروعية خيار الشرط بعد العقد إلى الى }
\end{aligned}
$$

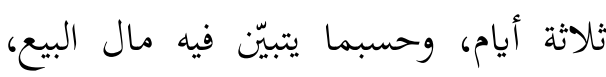

$$
\begin{aligned}
& \text { ولو إلى سنة في القرية ونخوها في مشهور } \\
& \text { مذهب مالك رحمه الله. } \\
& \text { ومن التراضي الضمني: بيع المعاطاة مطلقا } \\
& \text { فهو صحيح في رأي الجمهور غير الماطهي } \\
& \text { الشافعي)(). }
\end{aligned}
$$

Di antara kesempurnaan saling rela dalam transaksi adalah ditetapkannya hak pilih di lokasi transaksi. Ini merupakan pendapat Syafii, Ahmad, al-Laits dan lainnya.

${ }^{21}$ Wahbah ibn Muṣțafā Al-Zuhailī. (1422 H). Al-Tafsīr Al-Wasìt. Damaskus: Dar al-Fikr, Jilid 1, hlm. 310 . 


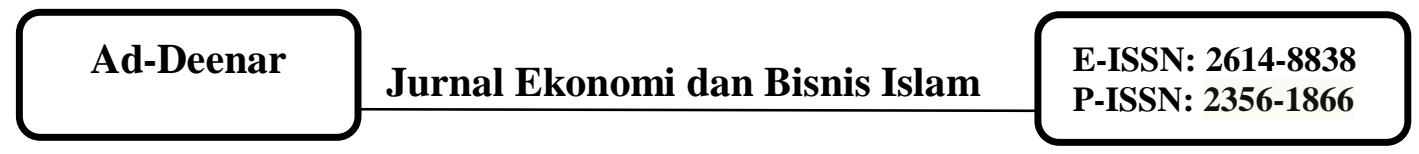

Karena berdasarkan hadis dalam Bukhari dan Muslim bahwa Rasulullah bersabda, "Jual beli itu ditetapkan dengan memberi hak pilih selama belum berpisah keduanya." Dalam riwayat Bukhari, "Apabila dua orang bertransaksi, maka kedua pihak tersebut memiliki hak pilih selama masih di lokasi transaksi."

Dengan demikian ayat ini dikhususkan dengan hadis. Termasuk dalam hal ini adalah memberikan hak pilih syarat selama tiga hari setelah akad. Bisa juga waktunya disesuaikan dengan kondisi harta dan komoditas yang dijual walaupun sampai satu tahun atau semisalnya di negeri tersebut menurut pendapat yang popular dalam mazhab Malik -Semoga Allah merahmatinya-.

Di antara bentuk saling rela adalah transaksi al-Mu'ātah (yaitu transaksi jual beli dengan cara saling memberi antara penjual dan pembeli yang tidak disertai ijab Kabul secara lisan). Transaksi seperti ini secara mutlak dibolehkan oleh mayoritas ulama kecuali Syafi'i. ${ }^{22}$

Jadi, menurut Al-Zuḥailī saling rela itu bentuknya ada tiga yaitu (1) Adanya ucapan Ijab Kabul (2) Adanya pemberian hak pilih (3) Perilaku atau perbuatan yang menunjukkan saling rela.

\section{E. Artikulasi 'An-Tarā dhīn dalam Ekonomi Islam}

Dalam perkembangannya, para ulama menyimpulkan dari dalil-dalil Al-Qur`an dan Hadis sebuah kaidah Fikih. Di antaranya tentang jual beli itu berdasarkan saling rela atau suka sama suka ( إنَّمَا الْبَيْعُ عَنْ تَرَاضٍ. Maka pada bagian ini akan dijelaskan tentang hakikat kaidah 'an-tarāọhīn.

\section{Asal Kaidah 'An-Tarä}

Maksud asal kaidah adalah dalil-dalil yang dijadikan sandaran untuk kaidah. ${ }^{23}$ Dalam hal ini, dalil yang dijadikan sandaran untuk kaidah ini yaitu:

Pertama, Surat An-Nisa Ayat 4.

$$
\begin{aligned}
& \text { (فَإِانْ طِبْنَ لَكُمْ عَنْ شَيٌٍٍْ مِنْهُ نَفْسًا }
\end{aligned}
$$

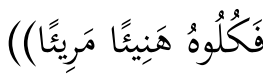

"Kemudian jika mereka (para istri) menyerahkan kepada kamu sebagian dari mahar itu dengan senang hati maka makanlah pemberian itu (sebagai makanan) yang sedap lagi baik akibat-nya." (Q.S. An-Nisa' [4]: 4)

Kedua, Surat An-Nisa Ayat 29 yang sudah dijelaskan tafsirnya di atas.

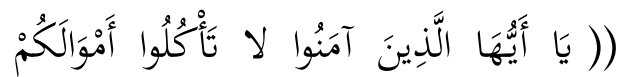

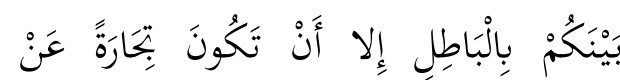

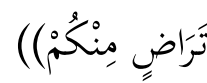

"Wahai orang-orang yang beriman, janganlah kamu saling memakan harta sesamamu dengan jalan yang bathil, kecuali dengan jalan perniagaan yang berlaku dengan suka sama suka diantara kamu." (Q.S. An-Nisa' [4]: 29)

22 Wahbah ibn Mușṭafā Al-Zuhailī. (1418 H). Al-Tafsīr Al-Munīr fī Al- 'Aqīdah wa Al-Syarī'ah wa Al-Manhaj, Damaskus: Dar Al-Fikr Jilid 5, hlm. 3435. 


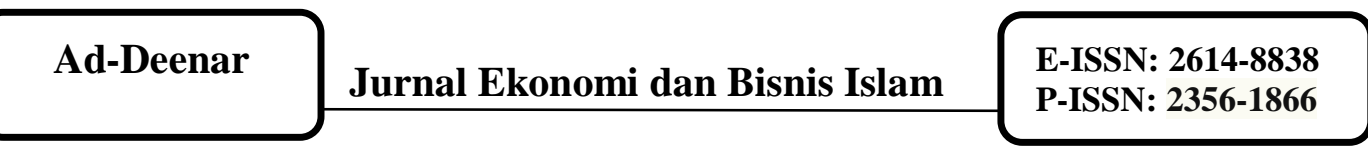

Ketiga: hadis dalam riwayat Ibn Majah No. 2185.

Hadis ini diriwayatkan oleh Ibn Majah dari jalur sahabat yang mulia Abu Sa'id AlKuhdri dan juga diriwayatkan oleh Ibn Hibban dalam kitab Sahihnya:

$$
\begin{aligned}
& \text { عن داود بن صالح المدني عن أبيه قال } \\
& \text { سمعت أبا سعيد الخدري يقول قال رسول } \\
& \text { الله صلى الله عليه و سلم إِنَّمَا الْبَيْعُ عَنْ } \\
& \text { تَرَاضٍ }
\end{aligned}
$$

Dari Dawud ibn Shalih al-Madani dari Bapaknya berkata. Aku telah mendengar bahwa Abu Said alKhudri berkata, Rasulullah bersabda, "Sesungguhnya jual beli itu berdasarkan saling rela." 24

Jadi, untuk memudahkan pemahaman tentang saling rela sebagai salah satu syarat transaksi ekonomi adalah dengan menghapal dan memahami kaidah ini, yaitu:

$$
\text { إِنَّمَا الْبَيْعُ عَنْ تَرَاضِ }
$$

"Sesungguhnya jual beli itu berdasarkan saling rela."

\section{Makna Kaidah 'An Tarādīn}

Berkaitan dengan makna kaidah ini, Ahmad Sabiq Abu Yusuf menguraikan secara terperinci dari beberapa ulama, di antaranya Al-Nadwi dalam kitabnya Jamharotul Qowaid Fiqhiyah mengatakan

${ }^{24}$ Muhammad ibn Yazīd Abū 'Abdillāh AlQazwain̄̄. Sunan ibn Mājah. Beirut: Taḥīq: Muḥammad Fuād 'Abd al-Bāqī, Dar al-Fikr, Jilid 2, hlm. 737. bahwa ini adalah sebuah kaidah umum yang menunjukkan bahwa semua bentuk transaksi yang dilaksanakan berdasarkan rasa suka sama suka maka itu diperbolehkan selagi tidak terdapat larangan dari Allah dan Rasul-Nya, namun jika bertentangan dengan larangan dari Allah dan Rasul-Nya meskipun dilaksanakan atas dasar suka sama suka maka itu jelas terlarang.

Demikian pula Ibnu Abdil Bar berkata dalam kitabnya Al-Istidzkar: "Setiap perdagangan yang di dasarkan atas dasar suka sama suka dan tidak terdapat larangan dari Rosululloh juga tidak semakna dengan yang terdapat larangannya maka itu diperbolehkan."

Berangkat dari dua ayat di atas, Syaikhul Islam Ibnu Taimiyah dalam kitabnya Majmuatul Fatawa membuat sebuah kaedah yang sangat berharga dalam bidang muamalat secara umum dan dalam bidang perdagangan secara khusus. Beliau berkata:

"Dasar dalam sebuah transakasi adalah rasa ridlo dari kedua belah pihakyang sedang mengadakan sebuah trasakasi, dan konsekuensi dari transaksi itu adalah yang disepakati oleh keduanya dalam akad."

Hal ini karena Alloh Ta'ala berfirman dalam Al-Qur'an: إلالأنْْ تَكُونَ تِجَارَةً عَنْ تَرَاضٍ "Kecuali dengan jalan perniagaan yang 
berlaku dengan suka sama suka diantara kamu." Juga firman-Nya: "Kemudian jika mereka (para istri) menyerahkan kepada kamu sebagian dari mahar itu dengan senang hati maka makanlah pemberian itu (sebagai makanan) yang sedap lagi baik akibatnya." Alloh Ta'ala menggantungkan bolehnya makan dengan kerelaan jiwa sebagai sebuah syaratnya yang menunjukkan bahwa kerelaan itulah yang menjadi sebab dihalalkanya hal tersebut. Dan kalau memang kerelaan jiwa itulah yang menjadikan boleh bagi seorang suami untuk memakan mahar istrinya maka begitu pula dengan sebuah bentuk shodaqoh, berdasarkan hukum kias terhadap masalah yang terdapat nashnya dalam ayat tersebut.

Begitu pula dengan firman Alloh dalam suat An-Nisa': 29 disitu Alloh tidak mensyaratkan dalam sebuah perdagangan kecuali sekedar rasa suka sama suka, hal ini menunjukkan bahwa rasa itulah yang menjadi sebab diperbolehkanya perdagangan. Dari sini maka kalau si penjual dan pembeli sudah suka sama suka atau orang yang bershodaqoh dilaksanakan dengan rasa rela maka hukumnya adalah halal berdasarkan nash dari Al-Qur'an, kecuali kalau mengandung sesuatu yang diharamkan oleh Alloh عزّوجلّ dan RosulNya."
Berangkat dari sini, maka bisa kita katakan: Kalau memang syarat utama dalam sebuah transaksi adalah rasa suka sama suka, maka semua ucapan dan perbuatan yang menunjukkan atas suka sama suka maka diperbolehkan dalam semua transakasi kecuali yang dikecualikan. Diantara yang dikecualikan adalah akad nikah, karena nikah harus dengan lafadl tertentu, tapi akad lainnya tidak harus dengan lafadl atau perbuatan tertentu.

Masih dalam kitabnya Majmuatul Fatawa, Syaikhul Islam Ibnu Taimiyah berkata: "Dasar dari semua transakasi yang berhubungan dengan harta benda adalah bahwasanya semua akad itu bisa sah dengan semua ucapan dan perbuatan yang bisa menunjukkan maksud dari akad tersebut."

Maka semua yang dianggap manusia sebagai sebuah jual beli dan sewa menyewa maka itulah jual beli dan sewa menyewa yang sah, meskipun mereka berbeda dalam cara mengungkapkan dan melaksanakan. Dan itu bisa berubah dengan perubahan situasi dan kondisi, kalau sebuah istilah yang dipakai oleh sebuah kaum itu berubah maka berubah pulalah cara transaksi. Kaedah yang kami sebutkan ini yaitu bahwasanya semua akad itu bisa sah dengan semua yang menujukkan pada tujuan dari akad tersebut, itulah yang ditunjukkan oleh syariat Islam dan itu pulalah yang diterima 
oleh akal sehat manusia. Di antara dalilNya adalah firman Alloh عزّوجل: "Kecuali dengan jalan perniagaan yang berlaku dengan suka sama suka diantara kamu." Juga firman-Nya: "Kemudian jika mereka (para istri) menyerahkan kepada kamu sebagian dari mahar itu dengan senang hati maka makanlah peberian itu (sebagai makanan) yang sedap lagi baik akibatnya."

Ayat pertama mengisyaratkan pada semua bentuk transaksi jual beli dan ayat kedua mengisyaratkan pada semua bentuk transakasi tabarru' (shodaqoh), tidak terdapat dalam keduanya harus disyaratkan lafadl dan perbuatan tertentu. ${ }^{25}$

\section{Pengecualian Kaidah 'An Tarādin}

Ahmad Sabiq Abu Yusuf menjelaskan bahwa terdapat beberapa hukum yang dikecualikan dari kaedah di atas:

a. Semua transaksi yang diharamkan oleh Allah dan Rasul-Nya meskipun dilaksanakan dengan dasar suka sama suka.

Seseorang yang berhutang satu juta rupiah, namun dengan perjanjian bahwa saat mengembalikanya harus satu juta seratus ribu rupiah dan ini dilaksanakan dengan kerelaan kedua belah pihak, maka ini haram karena ini adalah bentuk riba.

25 Ahmad Sabiq Abu Yusuf, Kaidah Fikih: Jual Beli Itu Berdasarkan Atas Rasa Suka Sama Suka, e Book, www.ibnumajjah.com, Publikasi 2016.
Begitu pula dengan bunga yang diambil oleh seorang penabung dari bank konvensional, meskipun dilaksanakan atas dasar suka sama suka, dan saling menguntungkan maka juga terlarang karena termasuk perbuatan riba.

b. Dalam keadaan-keadaan tertentu boleh bagi pemerintah untuk mengambil paksa dan menyita harta seseorang apabila terdapat hal yangmengharuskan melakukan itu. Misalkan seseorang yang sudah wajib mengeluarkan zakat tapi tidak mau mengeluarkanya maka separoh hartanya disita oleh negara. Berdasarkan sabda Rosululloh:

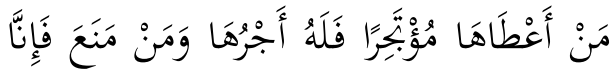

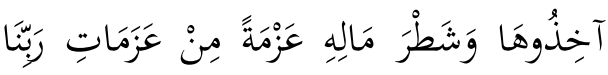

$$
\begin{aligned}
& \text { عَزَّ وَجَجلَّ }
\end{aligned}
$$

"Barangsiapa menunaikan zakat ini dengan mengharapkan pahala maka dia akan mendapatkan pahalanya, namun barangsiapa yang menahannya maka kami akan mengambilnya dengan separoh hartanya, sebagai sebuah kewajiban dan beberapa kewajiban Alloh." (H.R. Abu Dawud: 160, Nasa'i 5/25 dan dishohihkan oleh Syaikh Al-Albani sebagaimana dalam Shohihul Jami': 4265)

c. Begitu juga pemerintah boleh untuk tidak mensahkan transaksi seseorang meskipun dilaksanakan atas dasar suka sama suka kalau mengakibatkan kerugian yang sifatnya umum bagi yang lainnya. Misalkan seorang yang sedang punya hutang banyak pada 


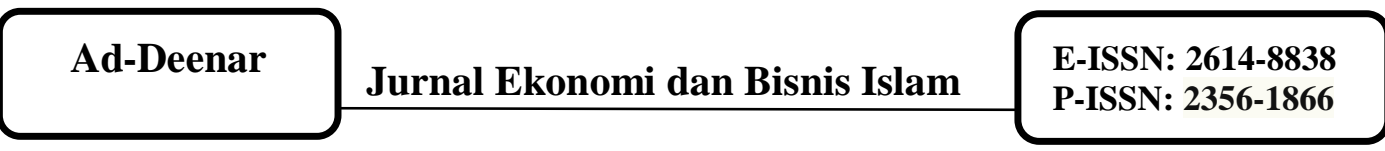

beberapa orang, dan dia mengalami kebangkrutan sehingga tidak bisa melunasi, maka pemerintah berhak untuk tidak mensahkan semua transakasi keuangan dia demi kemaslahatan orang-orang yang menghutanginya. Sebagaimana dijelaskan oleh para ulama' dalam bab muflis (orang yang bangkrut).

d. Orang yang mempunyai hak atas orang lain, namun tidak ditunaikan. Maka boleh baginya untuk mengambilnya mekipun bukan atas kerelaan dari orang lain tersebut. Misalkan seorang istri yang tidak diberi nafkah oleh suaminya, padahal suaminya mampu memberi nafkah, maka boleh bagi si istri untuk mengambil harta suaminya meskipun bukan atas kerelaan si suami. Berdasarkan hadits Hindun binti Utbah. $^{26}$

\section{F. Hukum Saling Rela dalam Transaksi Ekonomi}

Adapun terkait dengan bentuk nyata saling rela dalam transaksi ekonomi, maka dari uraian tafsir Surat An-Nisa' Ayat 29 dapat disimpulkan menjadi tiga macam, yang masing-masing merupakan pandangan para ulama, yaitu:

26 Ahmad Sabiq Abu Yusuf. (2016). Kaidah Fikih: Jual Beli Itu Berdasarkan Atas Rasa Suka Sama Suka, e Book, www.ibnumajjah.com.
1. Saling rela tidaklah terrealisasi melainkan dengan perkataan berupa Ijab Kabul. Ini salah satu masalah yang menimpa umat Islam kontemporer. Karena sebagian transaksi ekonomi yang melibatkan uang dalam jumlah besar dilakukan melalui Bursa yang tanpa Ijab dan Kabul dengan perkataan. Akan tetapi melalui komputer yang terintegrasi dengan jaringan internet internasional. Sarana-sarana ini ditengarai memiliki kedudukan yang sama kuatnya dengan Ijab Kabul secara perkataan bahkan lebih kuat dan terpercaya.

2. Pada dasarnya saling rela itu ditunjukkan dengan perkataan tetapi boleh dengan perbuatan dalam transaksi yang banyak terulang Ijab Kabulnya. Ini merupakan pendapat yang ditoleransi oleh Ahli Fikih pendapat pertama. Contohnya, Anda memberi tukang roti uang kemudian ia memberimu roti dan kamu berdua sama-sama diam. Seperti Anda naik kendaraan dengan tariff yang sudah diketahui lalu Anda bayar dan diam. Demikian pula dengan mesin jual beli minuman (kita memasukkan uang ke mesin kemudian keluar minuman yang kita inginkan). Transaksi semacam ini para ulama Fikih menamakannya dengan al-Mu'ātah. Mereka mengatakan bahwa transaksi jual beli 


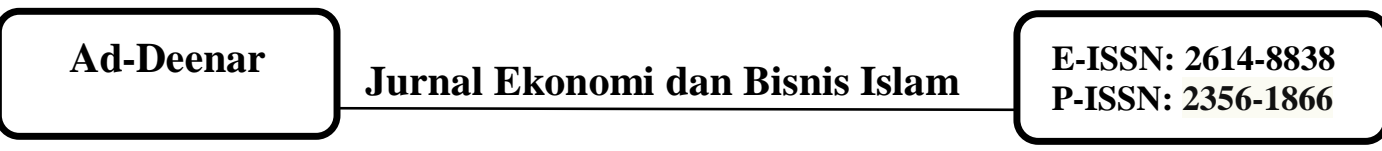

yang menuntut untuk banyak berijab rela, dan lain sejenisnya. Sehingga

Kabul dalam kehidupan sehari-hari, maka sah transaksinya dengan alMu'ạtah. Di mana tidak disyaratkan adanya Ijab dan Kabul secara perkataan.

3. Saling rela itu terwujud dengan segala bentuknya baik perkataan maupun perbuatan. Ini merupakan pandangan Ibn Taimiyah. Contohnya transaksitransaksi yang digulirkan melalui Bursa. Di mana hanya beberapa menit bahkan persekian detik dengan regulasi yang disepakati, transaksi antar perusahaan itu terwujud dan masingmasing pihak saling rela. Semua model transaksi ini sah secara hukum Islam. Demikian pula transaksi-transaksi alMu'ātah yang menunjukkan kerelaan baik perkataan maupun perbuatan di masa mendatang yang tidak ada saat ini, maka transaksi itu juga sah.

Akan tetapi tentunya harus disepakati terdahulu antara perusahaan atau penjual dan pembeli regulasi tertentu yang menunjukkan kerelaan. Seperti nomor Visa yang tertulis di internet yang menunjukkan identitas pemiliknya. Seandainya seseorang tidak rela, pasti ia tidak mau meletakkan PINnya (ATM) ketika melakukan transaksi. Bahkan, terkadang Anda memberi PIN tersebut melalui HP yang menunjukkan saling

yang paling penting adalah adanya sarana atau instrument yang mewujudkan syarat saling rela walaupun tanpa adanya Ijab dan Kabul dengan perkataan. ${ }^{27}$

\section{G. Implementasi Kajian pada Transaksi Ekonomi Islam Kontemporer}

Sebagaimana telah dijelaskan sebelumnya, bahwa hakikat saling rela yang dilegalkan secara syariat Islam dalam transaksi ekonomi itu mengerucut secara global menjadi dua varian. Pertama, secara eksplisit; yaitu berupa (1) pemberian hak pilih bagi pembeli dan penjual untuk melanjutkan akadnya atau membatalkannya secara perkataan (2) berpisahnya secara fisik antara pembeli dan penjual dari tempat transaksi. Kedua, secara implisit; yaitu berupa perilaku-perilaku transaksi ekonomi yang secara kebiasaan masyarakat setempat mencerminkan saling rela.

Jika kajian teoritis ini diimplementasikan pada transaksi-transaksi ekonomi kontemporer, maka akan ditemukan berbagai dimensinya. Berikut ini beberapa di antaranya:

\footnotetext{
${ }^{27}$ Hāmid ibn 'Abdullāh al-'Iliy, Syurūt al-Bai' $F \bar{\imath} \quad a l$-Iqtișād al-Islāmī, https://ar.islamway.net/article/204/, diakses pada Rabu, 28 Februari 2018, pukul 10.30 WIB.
} 


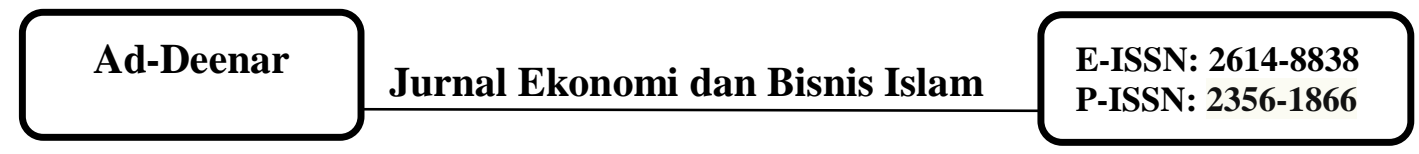

\section{Perkataan Ijab Kabul, Berpisahnya Fisik Kedua Pihak, dan Hak Pilih}

Saling rela dengan model seperti ini banyak terjadi di pasar-pasar tradisional, yang pada umumnya dalam menjalankan transaksinya tidak melibatkan mesin dan teknologi. Biasanya para pembeli datang ke pasar tersebut menuju tempat yang dituju untuk mencari barang yang sesuai keinginannya. Setelah sampai ke tempat tersebut, si pembeli melihat-lihat barang yang pas kemudian terkadang si penjual mengatakan, "dipilih...dipilih" atau yang semisalnya. Lalu si Pembeli jika merasa cocok akan menawar harga barang tersebut hingga disepakati harga tersebut antara kedua pihak. ${ }^{28}$

Hal ini juga kadang terjadi di warungwarung pinggiran yang tidak

28 Pasar tradisional adalah pasar yang pelaksanaannya bersifat tradisional tempat bertemunya penjual pembeli, terjadinya kesepakatan harga dan terjadinya transaksi setelah melalui proses tawar-menawar harga. Biasanya pasar tradisional umumnya menyediakan berbagai macam bahan pokok keperluan rumah tangga, dan pasar ini biasanya berlokasi di tempat yang terbuka.

Bangunan di pasar ini berbentuk toko dan kios. Toko semi permanen umumnya digunakan untuk berjualan aneka kue, pakaian, dan barang atau perabotan lainnya. Adapun los-nya yang digunakan untuk berjualan buah-buahan, sayuran, ikan, daging dan sebagainya. Penerangan di pasar tradisional secukupnya, dan tidak ber-AC. Kebersihan juga kadang kurang terjaga, seperti sampah banyak berserakan dan bertumpukan sehingga sering menimbulkan bau. Akibatnya jika turun hujan, akan becek dan kotor. Tapi semakin kesini kebersihan di pasar tradisional mulai di tingkatkan, bahkan sekarang ada pasar tradisional yang rapi dan bersih sehingga nyaman untuk dikunjungi. http://www.pengertianku.net/2015/04/pengertianpasar-tradisional-dan-ciri-cirinya.html, diakses pada 28 Februari 2018 pukul 16.06 WIB. mencantumkan harga barang. Seperti Warteg (Warung Tegal), Warung Padang, Warsun (Warung Sunda). Demikian pula dengan toko-toko meubel dan furniture, toko listrik, dan lain sebagainya. Intinya, dalam proses jual beli tersebut ada perkataan yang menunjukkan saling rela walaupun bahasa dan diksinya cukup variatif.

\section{Al-Mu'ātah}

Al-Mu'ạtah (yaitu transaksi jual beli dengan cara saling memberi antara penjual dan pembeli yang tidak disertai ijab Kabul secara lisan). Transaksi seperti ini secara mutlak dibolehkan oleh mayoritas ulama kecuali Syafii.

Transaksi jual beli seperti ini banyak ditemukan model dan variannya di pasarpasar model masa kini, seperti:

\section{a. Pasar Modern}

Pada dasarnya, pasar modern tidak jauh berbeda dari pasar tradisional, namun pasar modern terdapat penjual dan pembeli yang tidak bertransaksi secara langsung melainkan konsumen atau pembeli melihat label harga yang terdapat dalam barang tersebut, berada dalam bangunan serta pelayanannya dilakukan secara mandiri atau swalayan dan dapat juga dilayani oleh pramuniaga. Barang-barang yang dijual tersebut, selain dari bahan makanan, terdapat juga barang lainnya yang dijual dan biasanya 


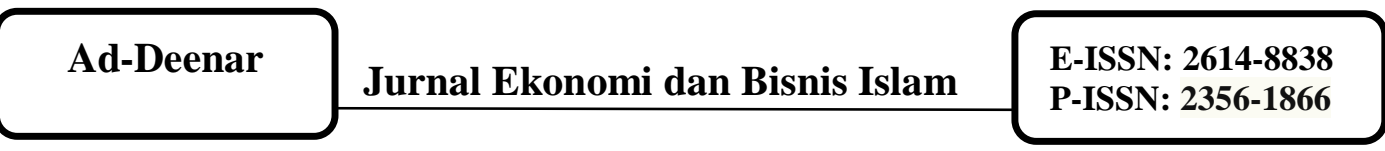

dapat bertahan lama. Contoh : mereka yang berkantong tebal atau minimarket, pasar swalayan untuk kelas menengah ke atas. Secara (supermarket), dan lain sebagainya. ${ }^{29}$

Saat ini, pasar modern bukan hanya ditemukan di kota-kota besar tetapi juga di wilayah-wilayah terpencil ditemukan minimarket-minimarket. Seperti Alfa Mart, Indo Maret, 212 Mart, dan lain sebagainya.

\section{b. Warung/Tempat Kuliner}

Termasuk dalam hal ini, adalah warung-warung makan dengan berbagai varian dan jenisnya terkadang menerapkan jual beli al-Mu'ātah seperti di pasar modern. Warung makan tersebut hanya membeberkan daftar menu makanan dan harganya kemudian si Pembeli memesan makanan yang diinginkannya.

Contoh model seperti ini adalah warung Martabak, Pecel Lele, Soto Lamongan, dan lain sebagainya. Secara teknis, ada yang pesan kemudian bayar setelah makanannya jadi. Ada juga yang pesan kemudian makan di tempat lalu membayar sesuai harga yang tercantum di daftar menu makanan.

\section{c. Restoran}

Restoran pada dasarnya mirip dengan warung makanan, hanya saja Restoran lebih diperuntukkan bagi

teknis biasanya, si pembeli memesan makanan yang ada pada daftar makanan dan harganya kemudian menyantap makanan tersebut lalu membayarnya.

\section{d. Pasar Abstrak}

Pasar abstrak merupakan sebuah pasar di mana terdapat para pedagang yang tidak menawar berbagai jenis barang yang dijual serta tidak membeli secara langsung, namun hanya menggunakan surat dagangan saja. Contoh dari pasar abstrak adalah pasar online, pasar modal, pasar valuta asing, dan pasar saham. ${ }^{30}$

Salah satu nikmat Allah kontemporer adalah ditemukannya internet yang menjadikan manusia bisa memiliki barang tanpa harus datang ke pasar langsung. Cukup membuka internet, maka akan banyak situs-situs yang menawarkan barang-barang kebutuhan hidup dari yang primer, sekunder hingga tersier. Situs-situs tersebut seperti shopee, bukalapak, blibli, tokobagus, dan lain sebagainya.

Secara teknis Si Pembeli biasanya memesan barang yang tercantum di situs dagang tersebut dengan harganya, pasar-jenis-jenis-pasar-fungsi-pasar.html, diakses pada 28 Februari 2018 pukul 16.48 WIB. 


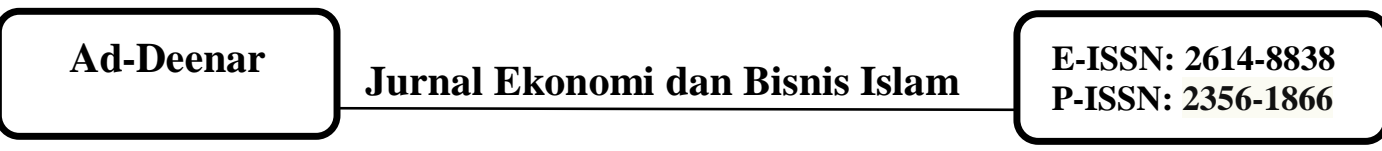

lalu si Penjual meminta supaya mentransfer sejumlah uang yang disepakati beserta ongkos kirimnya. Demikian pula dengan tiket transportasi baik mobil, motor, kereta, pesawat, dan kapal bisa dipesan melalui Online. Bahkan ada juga situssitusnya seperti traveloka, pegipegi, dan lain sebagainya.

Di samping itu, yang lebih canggih lagi semenjak ditemukannya aplikasi WhatsApp dan Telegram. Seseorang hanya dengan membuat grup-grup atau channel telegram, bisa menjalankan transaksi jual beli dengan cepat dan kilat.

Demikian beberapa bentuk saling rela dalam transaksi ekonomi yang terjadi di zaman modern saat ini. Bisa jadi, di masa mendatang akan ada model transaksi yang lebih canggih dari sekarang yang tidak diketahui oleh generasi masa kini.

\section{H. PENUTUP}

Dari penjelasan tersebut dapat disimpulkan sebagai berikut:

Pertama: 'An Tarādin secara linguistik bermakna saling rela. Adapun secara tafsir fikihnya dapat terrealisasi baik secara (1) eksplisit dengan perkataan Ijab dan Kabul (termasuk kata-kata 'pilihlah') dari kedua pihak dan berpisahnya fisik kedua pihak maupun secara (2) implisit dengan perilaku dan perbuatan yang menunjukkan saling rela yang disesuaikan dengan adat kebiasaan masyarakat setempat dan teknologi kontemporer.

Kedua: Bentuk saling rela dalam transaksi ekonomi kontemporer ini banyak ditunjukkan dengan perilaku, perbuatan, atau sarana yang regulasinya disepakati bersama antara kedua belah pihak, sehingga secara hukum Islam dinyatakan sah transaksinya.

\section{DAFTAR PUSTAKA}

Al-Qur'ân Al-Karîm dan terjemahannya.

Ahmadi, Abu. (2004). Sosiologi Pendidikan. Jakarta: Rineka Cipta, Cetakan Kedua.

Al-Dimashqī, A.I.K. (1999). Tafsīr AlQur 'ān Al-'Ażìm, 8 Jilid, Taḥqīq: Sāmī ibn Muḥammad Salāmah, Dār alTaibah.

Al-Māward̄̄, Abū Al-Ḥasan 'Alī ibn Muhammad ibn Muhammad ibn Habīb Al-Bașrī Al-Baghdādī. Tafsīr AlMāward̄̄: al-Nukat wa al-'Uyūn, 6 Jilid, Tahqīq: al-Sayyid ibn 'Abd alMaqșūd ibn 'Abd al-Rahīm, Dar alKutub Al-'Ilmiyah: Beirut Libanon.

Muḥammad Al-Ṭāhir ibn Muhammad ibn Muhammad Al-Ṭāhir ibn 'Āshūr AlTūnisi. (1984). Tahrīr Al-Ma'na AlSadìd wa Tanwīr Al- 'Aql Al-Jadìd Min Tafsīr Al-Kitāb al-Majīd. 30 Jilid, AlDar al-Tunisiah: Tunis.

Al-Yaman̄̄, Muhammad ibn 'Alī ibn Muhammad ibn 'Abdullāh AlSyaukānī. (1414 H). Fath Al-Qadìr, Beirut: Dar Ibn Katsir. 
Al-Qazwainī, Muhammad ibn Yazīd Abū 'Abdillāh. Sunan Ibn Mājah, 2 Jilid, Taḥqīq: Muḥammad Fuād 'Abd alBāqīi, Beirut: Dar al-Fikr.

Soekanto, S. (2012). Sosiologi Suatu Pengantar. Jakarta: Raja Grafindo Persada, Cetakan Ke-44.

Al-Ṭhabarī, Muhammad ibn Jarīr ibn Yazīd ibn Katsīr ibn Ghālib Al-Āmilī Abu Ja'far. (2000). Jāmi' Al-Bayān Fì Ta'wīl Al-Qur'ān, 24 Juz, Taḥqīq: Ahmad Muhammmad Syakir, Muassasah al-Risalah.

Tarmizi, E. (2017). Harta Haram Muamalat Kontemporer. Bogor: Berkat Mulia Insani.

Yusuf, A.S.A. (2016). Kaidah Fikih: Jual Beli Itu Berdasarkan Atas Rasa Suka Sama Suka, e Book, www.ibnumajjah .com, Publikasi.

Al-Zuhailī, Wahbah ibn Muștafā. (1418 H). Al-Tafsìr Al-Munīr Fì Al-'Aqìdah wa Al-Syarī'ah wa Al-Manhaj, 30 Jilid, Damaskus: Dar al-Fikr al-Mu'asir,

Al-Wahbah ibn Muștafā. (1422 H). AlTafsìr al-Wasitt, 3 Jilid. Damaskus: Dar Al-Fikr.

Muslimin, K. (2012). Pemikiran Al-Syatibi Tentang Maslahah, ASSETS, 2(2).

Maya, R. (2018). “Atensi Al-Qur'an Terhadap Anak Yatim (Studi Al-Tafsîr Al-Wasîth Karya Wahbah Al-Zuhailî).
Al-Tadabbur: Jurnal Ilmu Al-Qur'an dan tafsir. 03(02).

Wahidin, A. (0000) Tinjauan Dan Hukum Tasyabbuh Perspektif Empat Imam Mazhab, AL MASHLAHAH: Jurnal Hukum Islam dan Pranata Sosial Islam, 06(01).

Syamsul Hilal, Transaksi dalam Hukum Islam,http://ejournal.radenintan.ac.id/in dex.php/asas/article/view/1702, diakses pada Rabu, 17 Januari 2018, Pukul 11: 30 WIB.

https://sabq.org/KNDgde, diakses pada Senin 26 Februari 2018 pukul 10.48 WIB.

Ḥāmid ibn 'Abdullāh al-'Iliy, Syurūṭ alBai’ F̄̄ al-Iqtiṣād al-Islāmī, https://ar. islamway.net/article/204/, diakses pada Rabu, 28 Februari 2018, pukul 10.30 WIB.

http://www.pengertianku.net/2015/04/peng ertian-pasar-tradisional-dan-ciri-cirinya .html, diakses pada 28 Februari 2018 pukul 16.06 WIB.

http://woocara.blogspot.co.id/2016/01/peng ertian-pasar-jenis-jenis-pasar-fungsi-pa sar.html, diakses pada 28 Februari 2018 pukul 16.33 WIB.

http://woocara.blogspot.co.id/2016/01/peng ertian-pasar-jenis-jenis-pasar-fungsi-pa sar.html, diakses pada 28 Februari 2018 pukul 16.48 WIB. 